Caselet

\title{
The (un) Fruitful Training
}

\author{
Shreshth Chhabra
}

How to cite this paper: Chhabra, $\mathrm{S}$. (2021). The (Un) Fruitful Training.

Universal Journal of Business and Management, 1(2), 90-93. Retrieved from https://www.scipublications.com/journal/index.php/ujbm/article/view/146

Received: August 23, 2021 Accepted: September 24, 2021 Published: September 25, 2021

Copyright: (c) 2021 by the authors. Submitted for possible open access publication under the terms and conditions of the Creative Commons Attribution (CC BY) license (http://creativecommons.org/licenses /by/4.0/).

\author{
Member of Faulty, Daly College Business School, Indore (an affiliate of De Montfort University, UK) \\ *Correspondence: chhabrasonu@rediffmail.com
}

\begin{abstract}
Training is an essential HR function. Organizations impart training to make sure that their employees stay updated and up-skilled for the tasks assigned or to be assigned. To this end, it becomes important to give training based on certain criteria to assess the training needs. Whenever the training need assessment is not done properly, the context of training jeopardizes. The following case study is meant to be used as a supplement to teach the training need assessment. The case highlights the importance of training need assessment and how issues crop up when need assessment is not done appropriately.
\end{abstract}

Keywords: Training Need Assessment, Staff Development, Motivation, Biasness

\section{Theoretical Underpinning}

In today's dynamic environment, organizations are on their toes and they expect their employees to be faster, smarter and well-equipped to handle the challenges posed by the environment. In the context of any academic institution, especially higher education institutions, faculties need to be updated on recent trends, ongoing research in their field of interests and alike things so that they can contribute effectively to the development of own and students. Research [1], found that unable to attend to the training needs of faculty members have an adverse impact on the quality of educational delivery.

Training of the staff is one of the ways to keep them updated, motivated and improve their level of performance [2]. It will also help in increasing the productivity and improve growth rate of business [3]. To be effective, training needs should be uncovered to understand what will contribute the best to the individual, the department and the organization as a whole. [4]. A study, [5], highlighted that training need assessment played a positive role in improving employees' performance. An author [6] opined that training needs assessment points the areas where training programmes are most required. This permits the organization to apportion funds for training and development where they will have the greatest impact, thereby providing a positive return on the firm's investment. Similarly, another author [7], also emphasized that training needs assessment ensures that "the right training is delivered to the right people in the right way, and for the best results".

Training need assessment could be done through organizational analysis (present or future requirements of the organization), HR Audit (analyzing individual employee's development plans/ supervisors' inputs), Task Analysis (the work at hand), Performance analysis as available through performance appraisal and Mandatory training (based on legal requirement/ Training policy) [8,9] (HR-Guide LLC (2018), egyankosh (n d)) 


\section{The Case Situation}

Dr. Singh was heading the premier management institute. The institute offered undergraduate and post - graduate management programmes. The institute employed around 15 full time faculties.

Before Dr. Singh, institute was known but was not doing well. Dr. Singh and his team brought about a transformation and not only increased the number of seats but made the institute more visible to its stakeholders. He was a strong proposer of raising the standard of faculty inputs through motivating faculties to attend conferences, seminars and faculty development programmes and for these he needed funds. He believed that this will help faculties in better academic delivery to students and also in their PhD. or research work.

Dr. Singh had a word from management that if the admissions reach to a certain level, then management will allocate a definite fund for development of faculty staff. He also convinced management that this fund will be used in motivating faculty to do research, presenting their work in national and international conferences, attending faculty development programmes (FDP) and similar activities. These activities will not only help develop the faculty but will also help in networking at academia and industry level and help in brand building of institution.

Dr. Singh fulfilled his promise of admission to management and inturn management also granted funds (though not whole heartedly). Dr. Singh within the limitation of funds started sending faculties to primer institutions for attending conferences and specially FDPs. At one point of time on an average one faculty was attending a FDP every week. While choosing the faculty for any programme, Dr. Singh had a simple idea - he will circulate the information received of conference/ FDP amongst the faculty members and asked their desirability to participate. If more than one faculty showed interest then a 'decision by mutual consensus' was arrived at.

This practice continued for a year and things apparently looked well until, few faculty members started complaining of biasness and politicking in selection of faculty member for FDP and conferences. According to them 'favourite faculty members' were given preference and in some cases the information was not even floated to others and a decision was arrived at within the 'closed cabin'. Teachers also started questioning the way training need assessment done was by Dr. Singh in selecting the teacher for a training programme. They were of opinion that need assessment was neither based on subject the faculty member taught or intended to teach nor the research interest and candidates are chosen randomly. The so-called practice of circulating the notice of training / conference is carpeting the sending of "dear ones" to such programmes.

The matter was reported to management with 'proofs'.

\section{Discussion Questions}

Q.1. How should training need assessment be done to select the 'suitable' member of staff for training?

Q.2. What should management do after receiving the complaint with 'proofs'?

\section{Teaching Notes}

\subsection{Background}

The case is intended to highlight the aspect of Training Need Assessment (TNA) as a part of training and development efforts by organization. TNA assures that right content is delivered to the employee who actually needs it. This will ensure that training brings in the desired changes or results which will further help in training evaluation. The 
teacher should motivate the students to look into the references cited in the manuscript to help students get better understanding of TNA and related aspects.

\subsection{Target audience}

This caselet is meant for students at undergraduate or post graduate level, studying HR as a subject. It should be used as a supplement to teach Traning Need Assessment.

\subsection{Leading the discussion}

The case clearly states that Dr. Singh's TNA was not based on the subject the faculty taught or was being prepared for - this could be an allegation too. Because if this was the case, then how was a faculty chosen for training? Even if we assume that the choice of faculty was purely based on 'favoritism', then the training organization should have raised an objection to this. For example, a HR faculty send for training programme of digital marketing. The next aspect could be why would a faculty member go for a subject that was not related to his field or subject area of his/her specialization because that will be wastage of efforts and time.

\section{4. $Q \mathcal{E} A$}

- Q.1. How should training need assessment be done to select the 'suitable' member of staff for training?

The first answer may be obvious - the faculty should be chosen based on the subject taught or area of specialisation. However, the further question to ponder over - Institute will have multiple faculties with same specialisation - then how should a 'suitable' person be chosen? One criterion could be seniority in the reverse order - junior faculty needs more training. The other could be student feedback third willingness of faculty member and fourth could be random and fifth could be taking a choice and if two faculty members show inclination towards the same programme then either a mutual consensus or a simple toss (may be) - this was already in practice as per the case.

- Q.2. What should management do after receiving the complaint with 'proofs'?

If Management finds the 'proofs' to be valid, then it must ask Dr. Singh to set up a fair system of TNA based on one of the above criterions or mix or two criteria. Dr. Singh should also be asked to ensure that all faculty members are trained / everyone gets an equal opportunity to attend the training programme and if any favoritism exits then it should be undone immediately and no such complains or issues should ever come up.

\subsection{Conclusion}

The educator should highlight the issues / problems that could surface because of inappropriate TNA - i. e. wastage of time, money, efforts, morale and being trained for the sake of training.

\subsection{Issues that cropped up during the class}

During the discussion of the second question, students started suggesting the correction in training need assessment is one aspect but management should also look in the 'proofs' provided and if found valid should initiate action against Dr. Singh for politicking, inappropriate use of resources and de- moralizing employees. 


\section{References}

[1] Seyoum Y (2012), "Staff Development as an Imperative Avenue in Ensuring Quality: The Experience of Adama University", Education Research International, vol. 2012, Article ID 624241, https://doi.org/10.1155/2012/624241.

[2] Dolan S L and Capell B (2015), Training, Education, and Development of Staff, available from https://www.researchgate.net/publication/286879364_Training_Education_and_Development_of_Staff, accessed on 06/08/2021.

[3] Sharma R (2018), A Study on Training Need Analysis of Employees, Amity Journal of Training and Development3 (1), pp-2235, available from https://amity.edu/userfiles/admaa/89647Paper\%203.pdf, accessed on 06/08/2021.

[4] Bansal A and Tripathi J P (2017), Literature Review on Training Need Analysis, IOSR Journal of Business and Management, 19 (10), available from https://www.iosrjournals.org/iosr-jbm/papers/Vol19-issue10/Version-6/H1910065056.pdf, accessed on 06/08/2021.

[5] Kazi T M, Wahid I S and Arif I J B-M (Reviewing editor) (2019) Impact of training needs assessment on the performance of employees: Evidence from Bangladesh, Cogent Social Sciences, 5(1), DOI: 10.1080/23311886.2019.1705627

[6] McClelland S.B. (1993), "Training Needs Assessment: An "Open-systems" Application", Journal of European Industrial Training, 17(1), https://doi.org/10.1108/03090599310023691

[7] Andriotis N(2019), Why You Need To Run A Training Needs Assessment (And How To Do It), available from https://elearningindustry.com/why-need-to-run-training-needs-assessment, accessed on 06/08/2021.

[8] HR-Guide LLC (2018), Needs Analysis: How to determine training needs, available from https://hr-guide.com/Training/Determining_Training_Needs.htm, accessed on 06/08/2021.

[9] Egyankosh (nd), Training needs assessment, available from https://egyankosh.ac.in/bitstream/123456789/42117/1/Unit-1.pdf, accessed on 06/08/2021. 